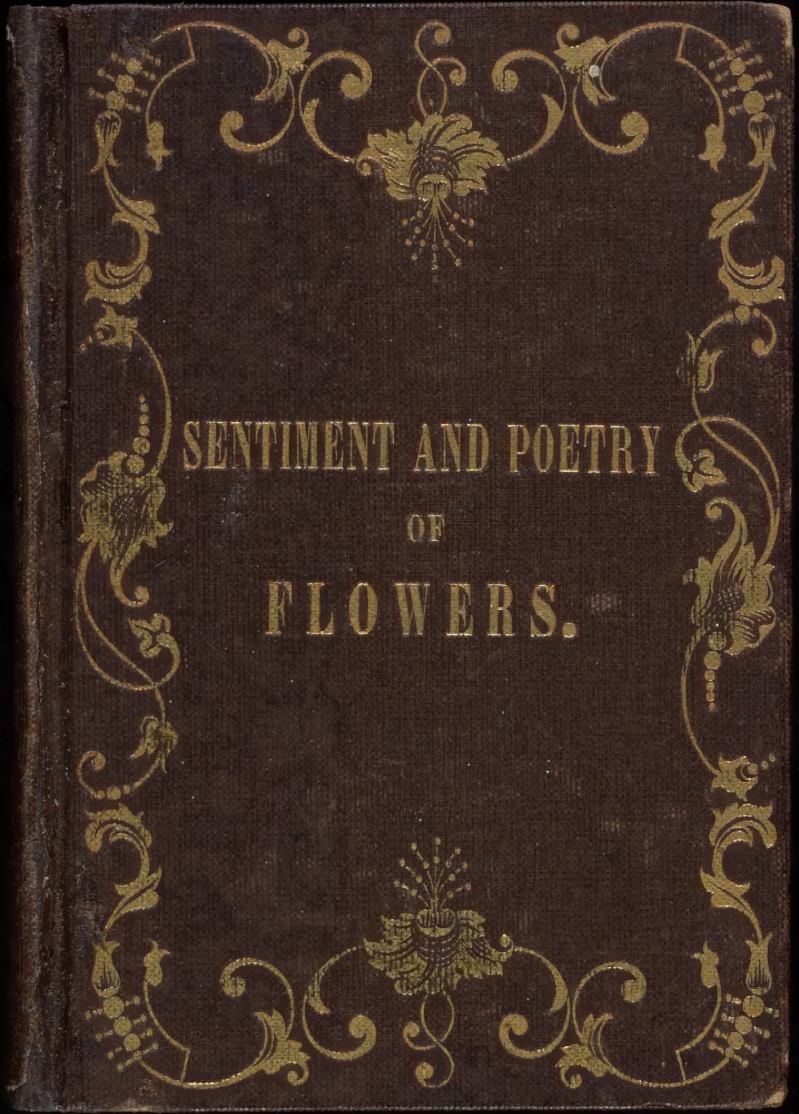




\section{Library of \\ James Moretz}




$$
3500
$$




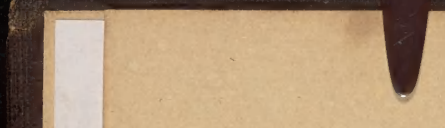

$$
\text { c. }
$$






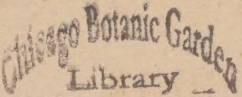


THF

\section{HAND BOOK}

or THE

\section{SENTIMENT AND POETRY}

OF

FL OWERS.

SECONDEDITION.

BOSTON:

PUBLISHED BY SAXTON AND KELT, 133 Wushington Street.

NEW YORE : SAXTON AND MILES.

1845. 

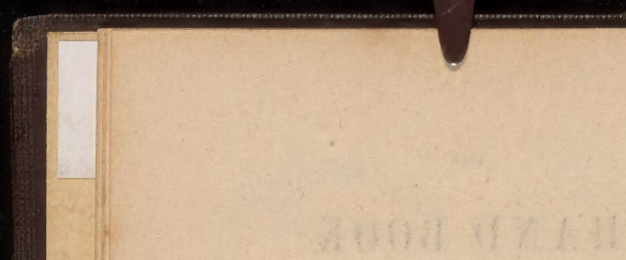



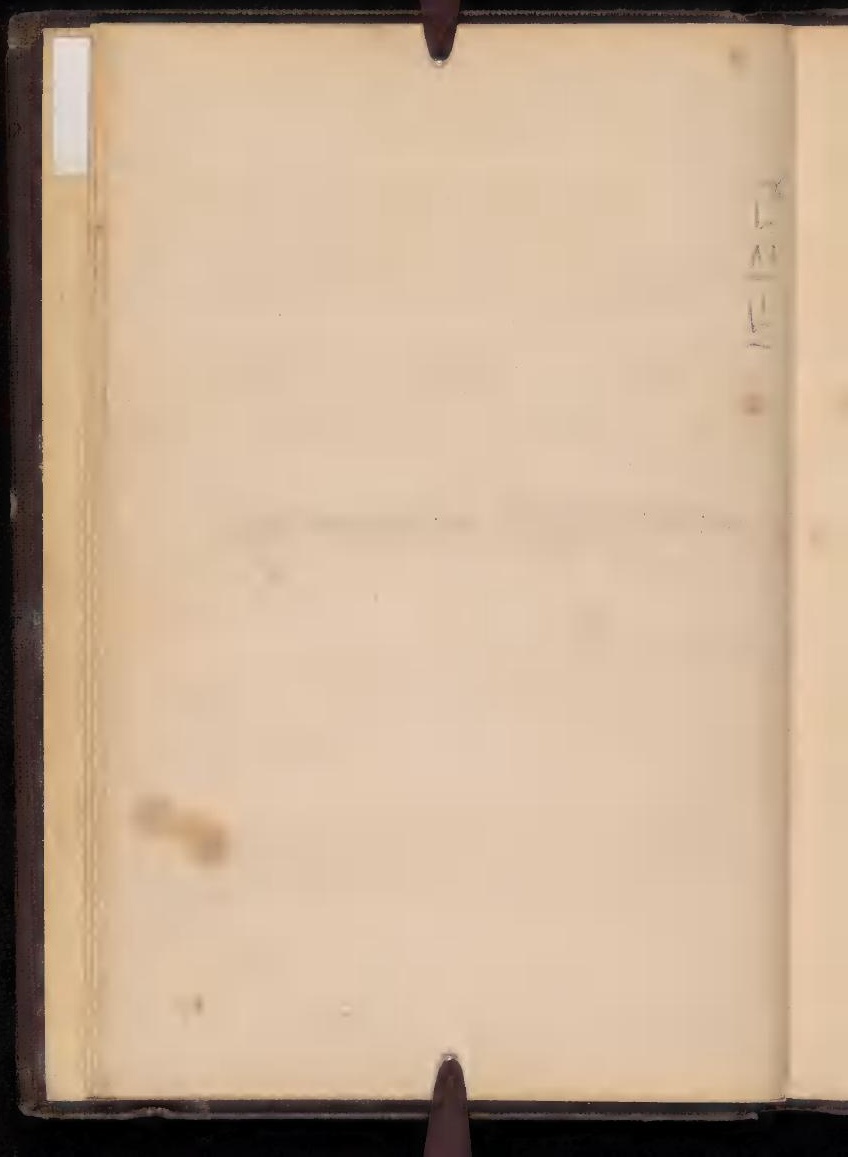




\section{A BOUQUET.}

In Eastern land they talk in flowers, And they tell in a garland their loves and cares ;

Each blossom that blooms in their garden bowers,

On its leaves a mystic language bears.

The rose is the sign of joy and loveYoung blushing love in its earliest dawn; And the mildness that suits the gentle dove, From the myrtle's snowy flower is drawn.

Innocence shines in the lily's bell,

Pure as a heart in its native heaven;

Fame's bright star and glory's swell

By the glossy leaf of the bay are given.

The silent, soft, and humble heart

In the violet's hidden sweetness breathes; And the tender soul that cannot part,

A twine of evergreen fondly wreathes. 
The cypress that darkly shades the grave, Is sorrow that mourns its bitter lot; And faith that $=$ thousand ills can brave, Speaks in thy blue leaves, forget-me-not.

Then gather a wreath from the garden bowers, And tell the wish of thy heart in flowers.

Percival.

Flowers to the fair! to you these flowers I bring,

And strive to greet you with an earlier spring; Flowers sweet and gay, and delicate like you, Emblems of Innocence and Beauty too.

With flowers the graces bind their yellow hair,

And flowery wreaths consenting lovers wear. Flowers, the sole luxury which nature knew, In Eden's pure and guiltless garden grew.

Mrs. Barbauld. 


\section{SENTIMENT OF FLOWERS.}

en bowent Howers.

IVAL,

flowers 1

er spring: like you 0,

yellor

rs wer.

knex,

ew.

AULD.

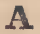

Abor Vitæ, - - - Live for me. Abor Vitæ, American, Immortality. Acacia, - - - - Chaste Love. Acacia, Yellow, - - Concealed Love. Acalea, - - - - Temperance. Acanthus, - - - The Arts. Achilla Millefolia, - War. Acontie Leaved Crowfoot, or Fair Maid of France, - - - Lustre. Adonis, - - - - Painful Recollections. Agnus Cactus, - - Coldness. To live without Love.

Agrimony, - - - Thankfulness. Almond, - - - - Heedlessness. Almond, Flowering, - Hope. Almond, Laurel, - - Perfidy. Aloe, - - - Acute sorrow or aftiction. 
Althea, Frutex, - - Persuasion.

Alyssum, Sweet, - - Worth beyond Beauty. Amaranth, - - - - Immortality.

A maranth, Globe, - Unchangeable. Amaryllis, - - - Pride. Ambrosia, - - - Love Returned. Anemone, - - - Frailty. Anemone, Field, - - Sickness. Anemone, Garden, - Forsaken. Angelica, - - - - Inspiration. Angree, - - - - Royalty. Apocynum, - - Falsehood. Apple Tree Blossom, Fame speaks him great and good. Apple Thorn, - - - Deceitful charms. Arum or Wake Robin,Ardor. Asclepias, - - - Cure for the heart ache. Ash, - - - - - Prudence. Ash, Mountain, - - Grandeur. Ash Leaved Trumpet

Flower, - - - Separation. Aspen Tree, - - Lamentation. Asphodel, - - - - My regret to follow you to the grave.

Aster, - - - - - Beauty in retirement. Auricular, - - - Painting. Auricular, Scarlet, - Pride. Azalea, - - - - Romance. 
Beauty,

Bachelors Button, - Hope in Love.

Balm, - - - A cure.

Balm, Gentle, - - Pleasantry.

Balm, of Gilead, - Healing.

Balsaam, - - Impatience.

Barberry, - - - Sourness.

Basil, - - - Hatred.

Bay berry, - - - Instruction.

Bay Leaf, - - - - I change but in dying.

Bay Leaf, Red, - - Love's memory.

m gres!

Bay Wreath, - - - Reward of merit.

is.

Bearded Crepis, - - Protection.

Beans Breach, - Art.

Beech Tree, - - - Grandeur.

Bell Flower, - - Constancy.

Bell Flower,PyramidalGratitude.

Bell Flower, White, - Thanksgiving.

Belvidere, - - - I I Ieclare against you.

Bee Orchis, - - - Industry.

Betony, - - - - Surprise.

Bilberry, - - - Treachery.

Bindweed, Great, - Dangerous Insinuations.

Bindweed, Small, - Obstinacy.

Birch, - - - - Gracefulness.

Bird Cherry, - - - Hope.

Bird's foot Treforl, - Revenge. 


\section{2}

Black Thorn, - - - Difficulty.

Bladder Senna, - Frivolous Amusement.

Blue Bottle Centuary, Delicacy.

Bonus Heuricæ, - - Goodness.

Borage, - - - - Bluntness or roughness

Box, - - - - - Constancy.

Bramble, - - - Remorse.

Branch of Currants, - You please all.

Branch of Thorns, - Severity or Rigor.

Broome, - - - Humility.

Broken Straw, - - Dissension.

Bryony, - - - - Prosperity.

Buck Bean, - - Calm Repose.

Burgloss, - - - Falsehood.

Bundle of Reeds with

their Paniclis, - - Music.

Butter Cup, : - - Childishness.

Butterfly Orchis, - - Gaiety.

\section{C}

Cabbage, - - - Profit.

Cactus or Indian Fig, I burn.

Cactus, Serpentine, - Horror.

Calla Ethiopica, - - Feminine Modesty.

Calycanthus, - - - Benevolence.

Campanula, - - Gratitude. 
ment.

Canary Grass, - Perseverancé.

Candy Tuft, - - Architecture.

Candy Tuft, Ever

Flowering, - - - Indifference.

Canterbury Bell, - - Gratitude.

Canter Bell, Blue, - Constancy.

Cardamine, - - - Paternal Error.

Cardinal's Flower, - Distinction.

Carnation, - - - - Pride and Beauty.

Carnation, Yellow, - Disdain.

Catesby Star Wort, - Afterthought.

Catalapa Tree, - - Beware of the Coquette.

Catchfly, - - - Artifice, pretended love.

Cedar of Lebanon, - Incorruptible.

Cedar Tree, - - - Strength.

Cedar Leaf, - - - Think of me.

Cereus, creeping, - Horror.

Cereus, Night Bloom-

ing, - - - - Transient Beauty.

Chamomile, - - - Energy in Adversity.

Chequered Fritillary, Persecution.

Cherry Tree Blossom, Spiritual Beauty.

Cherry Tree Cornelian, Majesty.

Cherry Tree, Wild, - Harshness.

Cherry Tree, Winter, Deception.

Cherval, Garden, - Sincerity.

Chestnut Tree, - - Render me justice.

China Aster or Chinese Starwort, - - Variety. 
Chinese Crysanthen- Cheerfulness in adversium, - - - - ty.

Cinquefort, - - - Beloved Daughter.

Circaea, - - Fascination.

Clematis, - - - Artifice.

Clematis, English, - Travellers' Joy.

Clover, - - - - Worth.

Clover, Purple, - - Provident.

Coboea, - - - Gossip.

Cockscomb or Crested

Amaranth, - - Singularity.

Colchicum or Meadow

Saffron, - - - My best days are past.

Coltsfoot, - - - Maternal Care.

Columbine, - - Desertion.

Convolvulus, Major, Extinguished Hopes.

Convolvulus, Minor, Night.

Convolvulus, Field, - Captivation.

Corchorus, - - - Impatience of absence.

Coreopsis, - - - Love at first sight.

Coriander, - - - Concealed merit.

Corn, - . - - - Riches.

Corinilla, - - - Success crown your wishes.

Cowslip, - - - Pensiveness.

Cowslip, American, - You are my divinity.

Crab Tree, - - - Deeply Interesting.

Cranberry, - - Hardiness. 
Creeping Cereus, - - Horror.

Cress, Indian, - - Resignation.

Crocus, - - - - - Cheerfulness.

Cross of Jerusalem, - Devotion.

Crowfoot, musk, - - Meekness.

Crown Imperial, - - Pride of Birth.

Cucumber, - - - Critic.

Cyclamen, - - - Diffidence.

Cypress, - - - - Mourning.

Cypress and Marygold,Despair.

past.

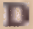

Daffodil, - - - Deceitful Hope.

Dahlia, - - - - Elegance and Dignity.

Daisy, - - - - Innocence.

Daisy, Double, - Participation.

Daisy, Garden, - I partake your sentiments.

Daisy, Michælmas, - Cheerfulness in old age.

Daisy, White, - - I will think of it.

Dandelion, - - - Coquetry.

Dapline Odora, - - Sweets to the sweet.

Darnel or Ray Grass, Vice.

Dew Plant, - - - Serenade.

Dead Leaves, - - Sadness.

Dittany, - - - Birth.

Dock, - - - Patience. 
Dodder, - - - Baseness.

Dogwood, or Cornel

Tree, - - - Durability.

Dragon Plant, - - Snare.

Ebony, - - - - Blackness.

Eglantine, - - - - I would wound to heal.

Eglantine, Full Blown, Simplicity.

Elder, - - - - Zealousness.

Elm, - - - - Dignity.

Elm, American, - - Patriotism.

Endive, - - - - Frugality.

Eupatoriam, - - - Delay.

Evergreen, - - - Poverty.

Evergreen Thorn, - Solace in adversity.

Everlasting, - - Never ceasing remembrance.

\section{F}

Fennel, - - - - Worthy of all praise.

Fern, - - - - Fascination.

Fern, Flowering, - - Reverie.

Fig, - - - - - Argument.

Fig, Marygold, - - Idleness.

Fig Tree, - - - Prolific. 
Filbert, - - - - Reconciliation.

Fir, - - - - - Time.

Fir, Scotch, - - - Grandeur.

Fir, Silver, - - Elevation.

Flix, - - - Fate.

Flax, Dried, - - - Utility.

Flax, Leaved Goldly

0 heal.

Locks, - - - Tardiness.

Floras, Bell, - - - You are without pretensions.

Flower of an hour, - Delicate Beauty.

Fly Orchis, - - Error.

Forget me not, - True Love.

Fox Glove, - - Insincerity.

Fraxinella, - - Fire.

Frankincense, - - The incense of faithfulness.

Frog Ophrys, - - - Disgust.

Fuchsia, - - - Confiding Love.

Fuchsia, Scarlet, - - Taste.

Fumitory, - - - Spleen.

ise.

\section{G}

Genista, - - - Neatness.

Gentian, - - - - Virgin Pride.

Gentian, Yellow, - Ingratitude.

Geranium, - - - Gentility. 
Geranium, Ivy, - Bridal Favor.

Geranium, Lemon, - Tranquility.

Geranium, Mourning, Despondency.

Geranium, Nutmeg, - An expected meeting.

Geranium, Oak, - - True Friendship.

Geranium, Rose, - - Preference.

Geranium, Scarlet, - Consolation.

Geranium, Silver leaf-

$$
\text { ed, - - - - Recall. }
$$

Geranium, Sorrowful, Melancholy spirit.

Gillyflower, - - - She is fair.

Gillyflower, Clove, - Dignity.

Glory flower, - - - Glorious Beauty.

Goat's Rue, - - Reason.

Golden Rod, - - - Precaution.

Goose Foot, - - Goodness.

Gorse, - - - - Cheerfulness in adversity.

Grape, Wild, - - - Charity.

Grape, Hamburg, - Sweetness.

Grass, - - - - Utility.

Grass, Vernal, - Poor but Happy.

\section{H}

Harebell, - - - - Delicate and Lovely. Hawkweed, - - Quicksightedness. 
Hawthorn, - - - Hope.

Hazel, - - - - Reconciliation.

Hazel, Witch, - - A spell.

Heart's Ease, - - - Love in idleness.

Heath, - - - - Solitude.

Helenium, - - - Tears.

Hellebore, - - - Calumny.

Heliotrope, - - Devotion.

Heliotrope, Peruvian, Intoxicated with pleasure.

Hemlock, - - - Youwill cause my death.

Henbane, - - - 1 mperfection.

Hepatica, - - - Confidence.

Hibiscus, - - - Delicate Beauty.

Hickory, - - - Glory.

Hoarhound, - - - Frozen Kindness.

Holly, - - - - Foresight.

Hollyhock, - - Fecundity.

Honesty or Satin

Flower, - - - Honesty.

Honey Flower, - Love sweet and secret.

Honeysuckle, - - - Bounds of Love.

Honeysuckle, Coral, Fidelity.

Honeysuckle, French, Rustic Beauty.

Honeysuckle, Wild, - Inconstancy.

Honeysuckle, Trum-

pet, - - . - - I have dreamed of thee. Hop, - - - - Injustice. 
Hornbean Tree, - Ornament.

Horse chestnut, - - Luxuriancy.

Hortensia, - - - - You are cold.

Housatonia, - - Content.

Houselock, - - Vivacity.

Hoya, - - - - Sculpture.

Hyacinth, - - - Play or games.

Hyacinth, Blue, - - Constancy.

Hyacinth, Purple, - Sorrow.

Hydsanga, - - - Heartlessness.

\section{I}

Iceland Moss, - - - You freeze me.

Ice Plant, - - - An old Beau.

Ipomoca, - - - Attachment.

Ipomoca, Scarlet, - I attach myself to you.

Iris, - - - - - My compliments.

Iris, Yellow, - - Flame of Love.

Ivy, - - - - Fidelity in Friendship.

\section{J}

Japonica, Camellia, - My destiny is in your hands.

Japonica, Pyrus, - - Fairies' Fire. Japonica, White, - - Purity.

Japonica, Volkameni-

ca, - . - May you be happy. 
Jasmine, - - - Amiableness.

Jasmine, Indian, - - I attach myself to you.

Jasmine, Spanish, - Sensuality.

Jasmine, White, - Love without alloy.

Jasmine, Virginian, - Separation.

Jasmine, Yellow, - Grace.

Jonquil, - - - - Desire.

Judas Tree, - - Unbelief.

Juniper, - - - Asylum.

Justicia, - - - The perfection of female Loveliness.

\section{I.}

Kennedia, - - - Mental Beauty.

Kingcap, - - - I wish I was Rich.

you.

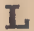

dship,

Laburnum, - - Pensive Beauty.

Ladies' Delight, - - Modesty.

Ladies' Slipper, - - Capricious Beauty.

Larch, - - - - Boldness.

your Larkspur, single Flow-

$$
\text { ered, - - - - - Levity. }
$$

Larkspur, double Flow-

ered, - - - - Haughtiness.

Lantana, Various Col'd Rigor.

Laurel, - - - - Glory. 
Laurel in flower,

Laurel, American,

Laurel, Mountain,

Lourestinus, - -

Lavendar, - - -

Lemon Blossoms,

Lettuce, - -

Lichon, - - -

Lilac, - - -

Lilac, Purple, - -

Lilac, White, - -

Lily,

Lily, Scarlet, - -

Lily, Tiger, - -

Lily, Water, - -

Lily, White, - -

Lily, Yellow, - -

Lily of the Valley,
Lime or Linden Tree

Linden Americe, Conjugal Fidelity.

Linden, American, - Matrimony.

Lobelia, - - - Arrogance.

London Pride, - Frivolity.

Lotus Flower, - - Silence.

Love in a mist, - - Perplexity.

Love in a puzzle, - Embarrassment.

Love lies a bleeding, Hopeless, not heartless.

Lucerne, - - - Life.

Lupine, - - - Voracious. 
Lychnis, - - - Religious Enthusiasm. Lythrum, - - - Pretensions.

\section{M}

Madder, - - - - Calumny.

Madwort, Rock, - - Tranquility.

Magnolia, - - - - Love of nature.

Magnolia, Laureled

Leaved, - - - - Dignity.

Maiden Hair, - - Discretion. Secresy.

Maize, - - - - Plenty.

Mallow, - - - Sweet Disposition.

Mallow, Marsh, - - Humanity.

Munchinel Tree, - - Falsehood.

Mandrake, - - - Rarity.

Maple, - - - - Reserve.

Marjorum, - - - Blushes.

Marvel of Peru, - - Timidity.

Marygold, - - - - Despair.

Marygold, African, - Vulgar Minds.

Marygold, French, - Jealousy.

Marygold, Small Cape Presage.

Marygold, Yellow, - Sacred affections.

Meadow Saftion, - - My best days are past.

ags.

Meadow, Sweet, - Uselessness.

Melon, Water, - - Bulkiness.

Melon, Mush, - - Crabbed. 
Mercury, - - - Goodness.

Mesembryanthenum, Idleness.

Mezereon, - - - Desire to please.

Mignonette, - - Your qualities surpass your charms.

Milk Vetch, - - Your presence softens

Milfoil, Common, - War.

Minosa, - - - Sensitiveness.

Mint, - - - - Virtue.

Misletoe, - - - Obstacles to be overcome.

Monkshood, - - - Knight Errantry.

Moonwort, - - Forgetfulness.

Moschatell, - - Weakness.

Moss, - - - - Ennui.

Moss, Tuft of, - - Maternal Love.

Motherwort, - - Concealed Love.

Mouse Ear, - - - Forget me not.

Mouse Ear Chickweed Ingenious simplicity.

Mouse Ear Scorpion

Grass, - - - - Forget me not.

Moving Planet, - Agitation.

Mulberry Tree, - - Wisdom.

Mulberry Tree, Black I will not survive you.

Mulberry Tree, Red, Prudence.

Mulberry Tree, White, Foresight.

Mullein, - - - Joyousness. 
FLOWERS.

Mullein, White, - Good Nature.

Mushroom, - - - - Suspicion.

Myrtle, - - - - Love.

Myrobalan - - Privation.

over.

\section{$\mathbb{N}$}

Narcissus, - - - Egotism.

Narcissus, False, - - Delusive Hope.

Narcissus, Poet's, - Fantastic Dreams.

Nasturtium, - - - Patriotism.

Nasturtium, Scarlet, - Splendor.

Nettle, - - - - Slander.

Nettle, Stinging, - - Cruelty.

Nightshade, - - Dark Thoughts.

Nightshade, Enchant-

er's, - - - - - Witcheraft.

Nightshade, Bitter-

ity.

sweet, - - - Truth.

Nosegay, - - - Gallantry.

\section{o}

yout.

Oak, - - - - Hospitality.

Oak Leaf, - - - - Bravery and Humanity.

Oak, Live, - - - - Liberty.

Oak, White, - - Independence.

Oats $_{1}$ - - - - - The Witching soul of man. 
26

SENTIMENT OF

Oleander, - - - Beware.

Olive, - - - - Peace.

Orchis, - - - - A Belle.

Orange Blossom, - - Wornan's worth.

Orange Flower, - Chastity.

Orange, Mock, - Counterfeit.

Orange Tree, - - - Generosity.

Osier, - - - - Frankness.

Ox Eye, - - - - Obstacle.

\section{P}

Palm, - - - - Victory.

Panseé or Hearts Ease, You occupy my thoughts.

Parsley, - - - Feast.

Passion Flower, - - Religious fervor.

Pea, - - - - - An appointed meeting.

Pea, Everlasting, - Lasting pleasure.

Pea, Sweet, - - Departure.

Peach Blossom, - - I am your captive.

Penny Royal, - - Flee away.

Pentunia, - - - You are less proud than they deem thee.

Peony, - - - - Bashful shame.

Pepper Plant, - - Satire.

Periwinkle, - - - Pleasures of memory.

Periwinkle, Blue, - Early Friendship. 
FLOWER.

Periwinkle, Red, - - False Hearted.

Periwinkle, White, - Remembrance.

Persecaria, - - - Restoration.

Persimon, - - - Bury me amid Nature's Beauties.

Pheasant's Eye, - - Sorrowful Remembrance.

Phlox, - - - Unanimity.

Pimpernal, - - - Assignation.

Pine, - - - - Pity.

Pine Apple, - - - You are perfect.

Pine, Pitch, - - Time and Philosophy.

Pine, Red, - - - Lively and pure love.

Pine, Spruce, - - Hope in adversity.

Pink, - - - - Always lovely.

Pink, Carnation, - - Elegance and Beauty.

Pink, Cuckoo, - Ardor.

Pink, Indian, - - Aversion.

Pink, Mountain, - - Aspirings.

Pink, Red, - - - - Woman's Love.

Pink, Sea, - - - Dauntlessness.

Pink, Striped, - - - Refusal.

Pink, White, - - Fair and fascinating.

Plane Tree, - - - You are perfect.

Plum Tree, - - Independence.

Plum Tree, Wild, - Keep your promises.

Polyanthus, - - - Confidence.

Pomegranite, - - Foolishness. 
Poplar, - - - - Talent.

Poplar, White, - - Time.

Poplar, Black, - - Courage.

Poppy, - - - - Consolation to the sick.

Poppy, Red, - - - Evanescent pleasures.

Poppy, Scarlet, - - Fantastic Extravagance.

Poppy, White, - - Forgetfulness.

Potato, - - - - Beneficence.

Prickly Pear, - - - Satire.

Pride of China, - Dissension.

Primrose, - - - Early youth.

Primrose, Evening, - Inconstancy.

Primrose, Rose Col'd, Unpatronised merit.

Privet, - - - - Defence.

Quảmoclet, - - - Busybody.

\section{is}

Reed, Common, - - Complaisance.

Reed, Flowering, - Confidence in Heaven.

Rest Harrow, - - Obstacle.

Robin, Ragged, - - Wit.

Robin, Wake, - - Ardor.

Rhododendron, - Danger.

Rocket, - - - Rivalry. 
Rocket, Queen's, - You are the queen of Coquettes.

Rose, - - - - Genteel. Pretty.

Rose, Acacia, - - Elegance.

Rose, Austrian, - - Very Lovely.

Rose, Bridal, - - - Happy Love.

Rose, Burgundy, - - Simplicity and Beauty.

Rose, Camphor, - - You are without pretension.

Rose, Carolina, - - Love is dangerous.

Rose, China, - - - Grace.

Rose, Chinese Dark, Forsaken.

Rose, Crown of, - - Reward of merit.

Rose, Daily, - - - Lightness.

Rose, Damask, - - Freshness of Complexion.

Rose, White Damask, Youth.

Rose, Red Damask, - Bashfil love.

Rose, Deep Red, - - Bashful shame.

Rose, Full Blown, - Beauty.

Rose, Guelder, - - Winter or age.

Rose, hundred leav'd, Grace.

Rose, Japan, - - - Beauty is your only attraction.

Rose, May, - - - Precocity.

Rose, Monthly, - - Beauty ever new.

Rose, Moss, " - - - Voluptuous Love.

Rose, Multiflora, - - Many charms. 
Rose, Mandi, - - - You are merry.

Rose, Musk, - - Capricious Beauty.

Rose, Red Leaved, - Beauty and prosperity.

Rose, Rock, - - - Poplar favor.

Rose, Sweet Briar, - Imagination.

Rosc, Thornless, - - Ingratitude.

Rose, White, - - - Sadness.

Rose, (White Wither-

ed,) - - - - - I am in despair.

Rose, Wild, - - - Love's messenger.

Rose, Yellow, - - - Let us forget.

Rose, York and Lan-

caster, - - - War.

Rose Bud, Moss, - - Confession.

Rose Bud, Red, - - Pure and lovely.

Rose Bud, White, - Too young to Love.

Rose Leaf, - - - - I never importune.

Roses, Garland of, - Reward of virtue.

Rusebay, Willow HerbCelibacy.

Rosemary, - - - Fidelity.

Rudbeckin, - - Justice.

Rue, - - - - - Grace.

Rush, - - - Docility.

Saffron, - - - Error is dangerous.

Saffron Flower, - Marriage. 
Safiron Crocus, - Mirth.

Sage, - - - - Domestic Virtues.

Sage, Garden, - - - Esteem.

Scabius, - - - Unfortunate attachment.

Sardony, - - Irony.

Saxifrage, Mossy, - Maternal Love.

Sensitive Plant, - - Bashfulness.

Service 'Tree, - - - Prudence.

Shaking Saintfoin, - Agitation.

Shanks, Red, - - - Patience.

Snap Dragon, - - - Presumption.

Snow Ball, - - - Thoughts of heaven.

Snow Drop, - - Thoughts of Consolation.

Spindle Tree, - - Your image is engraven on my heart.

Sorrel, - - - Wit, ill-timed.

Sorrel Wood, - - Maternal 'Tenderness.

Southern Wood, - - Boy's Love.

Speedwell, - - - Female Fidelity.

Speedwell, Spiked, - Adroitness.

Speedwell, Wall, - Fidelity.

Spider Ophyrs, - - Skill.

Spider Wort, - - - Transient Happiness.

Spiral Hypericum Fru-

tex, - - - - Uselessness.

St. Johns Wort, - - Superstitious Sanctity. 
Star Wort, - - - After-thought. Star of Bethlehem, - The Light of our path. Stock, - - - - Last Beauty. Stock, ten weeks, - Promptitude. Stramonium, common, Disguise. Strawberry, - - - Perfect goodness. Sumac, - - - - Splendor. Sumac, Venice, - - Intellectual Excellence. Sun Flower, - - False Riches. Sun Flower, Dwarf, - Your devout adorer. Sun Flower, Pale, - Lofty and Pure Swallowwert, - - Medicine. Sweet Briar, - - - Poetry. Sweet Flag, - - - Fitness. Sweet Sultan, - - - Felicity. Sweet William, - - Craftiness. Sycamore, - - - Woodland Beauty. Syringa, - - - Memory. Syringa, Caroline, - Disappointment.

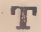

Tamarash, - - - Crime.

Tansy, - - - - Resistance.

Teasel, - - - - Misanthropy.

Teasel, Fullers, - - Austerity. Thistle, Common, - Importunity. 
Thrift, - - - Sympathy.

Throat Wort, - - Neglected Beauty.

Thyme, - - - Activity.

Tiger Flower, - - - For once may pride befriend me.

Tree of Life, - - - Old age.

Trefoil, - - - - Providence.

Tremilla Nostoe, - - Resistance.

Trumpet Flower, - Separation.

Truffle, - - - - Surprise.

Tubernose, - - I have seen a lovely girl.

Tulip, - - - Declaration of Love.

Tulip, Red, - - I love you.

Tulip Tree, - - Rural Happiness.

Tulip, Variegated, - Beantiful eyes.

Turnip, - - - Charity.

Tussilage, - - - Consolation.

Tussilage, Sweet

Scented, - - - You shall have Justice.

\section{V}

Valerian, - - Accommodating Disposition.

Valerian, Greek, - - Rupture.

Verbena, - - - Sensibility.

Vervain, - - - Superstition. 


\section{SENTIMENT OF FLOWERS.}

Venus's Fly Trap, - Deceit.

Venus's Looking GlassFlattery.

Violet, - - - - Rustic Beauty.

Violet, Blue, - - Faithfulness.

Violet, White, - - Modesty.

Violet, Yellow, - - Rural Happiness.

Vine, - - - - Drunkenness.

Virgin's Bower, - - Artifice.

Virginian Spider Wort, Momentary Happiness.

\section{W}

Wall Flower, - - - Fidelity in Misfortune.

Walnut, - - - Intelluct.

Walnut, Black, - - Beauty.

Wax, Plant, - - Susceptibility.

Wheat, - - - Riches.

Whortleberry, - Treason.

Willow, - - - Forsaken.

Willow, Weeping, - Melancholy.

Willow, Herb, - Pretension.

Woodbine, - - - Fraternal love.

Wormwood, - Absence.

\section{Y $\mathbb{Z}$}

Yarrow, - - - Disdain.

Yew, - - - - Sorrow.

Zinnia, - - - Absence. 
POETRY OF FLOWERS. 


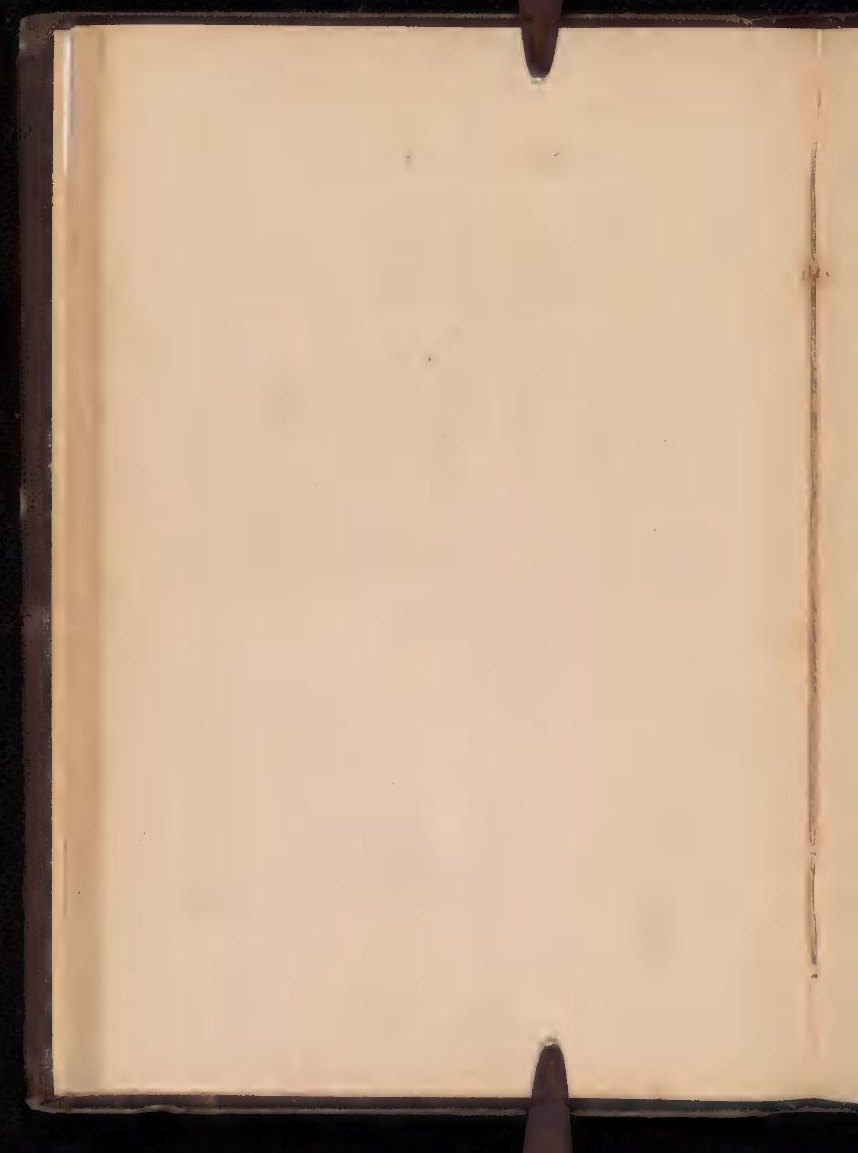




\section{POETRY OF FLOWERS.}

"There are few natural objects more poetical in their general associations than flowers: nor has there ever been a poet, simple or sublime, who has not adorned his verse with these specimens of nature's cunning workmanship. From the majestic sun-flower, towering above her sisters of the garden, and faithfully turning to welcome the God of day, to the little humble and well known weed that is said to close its crimson eye before impending shower, there is scarcely one flower which may not from its loveliness, its perfume, its natural situation, or its classical association, be considered highly poetical." 


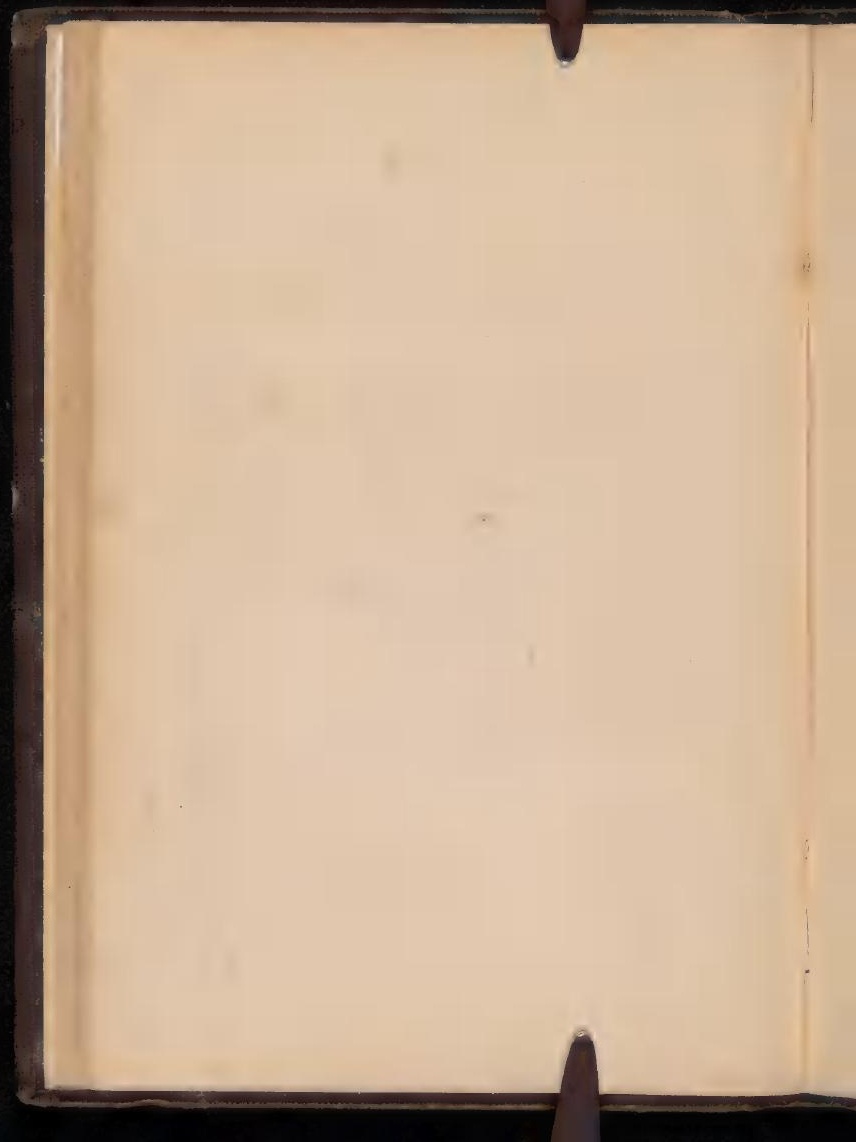




\section{TO A FLOWER.}

Dawn, gentle flower,

From the morning earth !

We will gaze and wonder At thy wondrous birth !

Bloom, gentle flower!

Lover of the light,

Sought by wind and shower,

Fondled by the night.

Fade, gentle flower !

All thy white leaves close;

Having shown thy beauty,

Time 'tis for repose.

Die, gentle flower

In the silent sun!

Lo,-all pangs are over,

All thy tasks are done! 
Day hath no more glory,

Though he soars so high;

Thine is all man's story,

Live-and love-and die!

Barry Cornwall.

\section{THE ROSE.}

Emria.-Of all flowers

Methinks the rose is best.

Servant.-Why, gentle madam?

Emilia.-It is the very emblem of a maid; For when the west wind courts her gently, How modestly she blows, and paints the sun With her chaste blushes! When the north comes near her Rude and impatient, then, like chastity, She locks her beauties in her bud again, And leaves him to base briars.

Beumont \& Fletcher. 
Roses at first were white, Till they could not agree Whether my Sappho's breast Or they more white should be.

But being vanquished quite, A blush their cheeks bespread; Since which, believe the rest, The roses first came red.

Herrick.

'Tis said, as Cupid danced among

- The Gods, he down the nectar flung;

Which on the white rose being shed,

Made it forever after red.

HeRRICK.

\section{MOSS ROSE.}

O! I love the sweet blooming, the pretty moss rose,

'Tis the type of true pleasure, and perfected joy. 
$O$ ! I envy each insect that dares to repose 'Midst its leaves, or among its soft beauties to toy.

I love the sweet lily, so pure and so pale, With a bosom as fair as the new-fallen snows; Her luxuriant odors she spreads though the vale,

Yet e'en she must yield to my pretty moss rose.

O! I love the gay hearts-ease, and violet blue, The sun-flower and blue-bell, each flow'ret that blows,

The fir-tree, the pine-tree, acacia, and yew; Yet e'en these must yield to my pretty moss rose.

Yes, I love my moss rose, for it ne'er had a thorn,

'Tis the type of life's pleasures, unmixed with its woes, 
FLOWERS.

'Tis more gay, and more bright, than the opening morn,

Yes, all things must yield to my pretty moss rose.

\section{TO E.-WITH A WITHERED ROSE.}

The rose you gave me, love, has lost The beauty of its blooming hour, But yet a fairy fragrance clings Around the ruined flower; And so the smile you gave me, love, Shone but an instant on my sight, And yet its memory remains To thrill me with delight. And now I give the rose again,

Content that memory should be The only thing to call me back To thought of love and thee. For lo, our lots are set apart, And mine is all too sad w way To shadow with its cypress boughs The morning of thy May. HENRY B. Hirst. 


\section{THE ROSE.}

O! how much more doth beauty beauteous seem

By that sweet ornament which truth doth give!

The rose looks fair, but fairer we it deem For that sweet odor which doth in it live. The canker blooms have full as deep a die As the perfumed tincture of the roses; Hang on such thorns, and play as wantonly, When Summer's breath their masked buds discloses.

But for their virtue only is their show, They live unwoo'd, and unrespected fade; Die to themselves. Sweet roses do not so, Of their sweet deaths are sweetest odors made;

And so of you, beauteous and lovely youth, When that shall fade, my verse distills your truth.

Shakspeare. 
FLOWERS.

\section{THE ALPINE FLOWERS.}

Meek dwellers mid yon terror-stricken cliffs! With brows so pure, and incense breathing lips, Whence are ye? Did some white winged messenger

On Mercy's mission trust your timid germ To the cold cradle of eternal snows? Or, breathing on the callous icicles, Bid them with tear-drops nurse ye?-Tree nor shrub Dare that dread atmosphere; no polar pine Uprears a veteran front; yet there ye stand, Leaning your cheeks against the thick ribbed ice

And looking up with brilliant eyes to Him Who bids you bloom unblanched amid the waste

Of desolation. Man, who, panting, toils O'er slippery steeps, or trembling treads the verge

Of yawning gulfs, o'er which the headlong plunge 
46

Is to eternity, looks shuddering up, And marks ye in your placid lovelinessFearless, yet frail-and clasping his chill hands Blesses your pencilled beauty. Mid the pomp Of mountain summits rushing on the sky, And chaining the rapt soul in breathless awe, He bows to bind you dronping to his breast. Inhales your spirit from the frost-winged gale, And freer dreams of heaven.

Mrs. L. H. Sigourney.

\section{HOW VIOLETS CAME BLEW.}

Love on a day, wise poets tell,

Some time in wrangling spent, Whether the violet should excel,

Or she in sweetest scent.

But Venus having lost the day,

Poore girles, she fell on you, And beate ye so, as some dare say Her blows did make you blew.

Herrick. 


\section{THE VIOLET.}

I love all things the seasons bring,

All buds that start, all birds that sing,

All leaves from white to jet;

All the sweet words that summer sends,

When she recalls her flowery friends,

But chief-the Violet !

I love, how much I love the rose,

On whose soft lips the south wind blows,

In pretty amorous threat;

The lily paler than the moon,

The odorous, wondrous world of June,

Yet more the Violet!

She comes, the first, the fairest thing That heaven upon the earth doth fling,

Ere winter's star has set;

She dwells behind her leafy screen,

And gives, as angels give, unseen

So love-the Violet.

What modest thoughts the violet teaches,

What gracious boons the violet preaches, 
Bright maiden, ne'er forget ! Bul learn, and live, and so depart, And sing thou, with thy wiser heart, Long live the violet.

Barry Cornwale.

\section{THE CROCUS.}

Dainty young thing

Of Life! thou venturous flower

Who growest through the hard cold bower

Of wintry spring.

Thou various hued,

Soft voiceless bell, whose spire

Rocks in the grassy leaves like wire

In solitude.

Like patience, thou

Art quiet in thy earth,

Instructing Hope that virtue's birth

Is feeling's vow. 
Thy fancied bride,

The delicate snow-drop, keeps

Her home with thee; she wakes and sleeps

Near thy true side.

Will man but hear!

A simple flower can tell

What beauties in his mind should dwell

Through passion's sphere.

\section{PrIor.}

\section{THE LILY OF THE VALLEY.}

I had found out a sweet green spot,

Where = lily was blooming fair;

The din of the city disturbed it not, But the spirit that shades the quiet cot

With its wings of love was there.

I found that lily's bloom,

When the day was dark and chill;

It smiled like a star in a misty gloom,

And it sent abroad a soft perfume,

Which is floating round me still.

3 
1 sat by the lily's bell,

And watched it many $\mathbf{a}$ day;

The leaves, that rose in a flowing swell

Grew faint and dim, then drooped and fell,

And the flower had flown away.

I looked where the leaves were laid, In withering paleness, by,

And, as gloomy thoughts stole on me, said There is many a sweet and blooming maid Who will soon an dimly die.

Percival.

\section{YEW AND CYPRESSE.}

Both you two have

Relation to the grave;

And where

The fun'rale trump sounds, you are there.

I shall be made

Ere long a fleeting shade;

Pray come

And doe some honor to my tomb. 
FLOWERS.

51

\author{
Do not deny \\ My last request, for 1 \\ Will be \\ Thankful to you, or friends for me. \\ HERRICK.
}

\title{
THE IVY.
}

The Ivy, that staunchest and firmest friend, That hastens its succoring arm to lend To the ruined fane, where in youth it sprung, And its pliant tendrils in sport were flung, When the sinking buttress and mouldering tower

Seem only the spectres of former power, Then the Ivy clusters around the wall, And for tapestry hangs in the moss-grown hall Striving in beauty and youth to dress The desolate place in its loveliness;In all seasons the Ivy is green and bright. Bright garlands of Ivy for Christmas night ! 
52 POETRY OF

\section{ORANGE FLOWERS.}

Bind the white orange flowers in her hair; Soft be their shadow, soft and somewhat pale, For they are omens. Many anxious years Are on the wreath that bends the bridal veil. The maiden leaves her childhood and her home, All that the past had known of happy hours, Perhaps her happiest ones-well may there be A faint, wan color, in those orange flowers. For they are pale as hope, and hope is pale With earnest watching over future years, With all the promise of their loveliness, The bride and morning bathe their wreath in tears.

L. E. Landon.

\section{THE WILD HONEY-SUCKLE.}

Fair flower, that dost so comely grow,

Aid in this silent, dull retreat,

Untouched thy honeyed blossoms blow,

Unseen thy little branches greet: 
No roving foot shall crush thee here, No busy hand provoke a tear.

By Nature's self in white arrayed, She bade thee shun the vulgar eye, And planted here the guardian shade, And sent soft waters murmuring by; Thus quietly thy summer goes, Thy days declining to repose.

Smit with those charms, that must decay,

I grieve to see your future doom;

They died-nor were those flowers more gay,

The flowers that did in Eden bloom;

Unpitying frosts and Autumn's power, Shall leave no vestige of this flower.

From morning suns and evening dews At first thy little being came:

If nothing once, you nothing lose,

For when you die you are the same;

The space between is but an hour, The frail duration of a flower.

Philip Frenean. 


\section{PRIMROSE.}

Mark in yonder thorny vale,

Fearless of the falling snows,

Careless of the chilly gale,

Passing sweet the Primrose blows.

Milder gales and warmer beams,

May the gaudier flow'rets rear;

But to me the Primrose seems

Proudest gem that decks the year.

\section{TULIP.}

Who thus, O Tulip ! thy gay painted breast

In all the colors of the sun has drest?

Well could I call thee, in thy gaudy pride,

The Queen of flow'rs; but blooming by thy side

Her thousand leaves that beams of love adorn,

Her throne surrounded by protecting thorn,

And smell eternal, form a juster claim,

Which gives the heaven-born Rose the lofty name,

Who, having slept throughout the wintry storm,

Now through the op'ning buds displays her smiling form.

KLeIST. 


\section{THE WILD CHERRY TREE.}

$\mathrm{O}$,- - there never was yet so fair = thing,

By racing river or bubbling spring,

Nothing that ever so gaily grew

Up from the ground when the skies were blue,

Nothing so brave-nothing so free As thou-my wild wild Cherry-tree!

Jove! how it danced in the gusty breeze!

Jove! how it frolicked amongst the trees!

Dashing the pride of the poplar down,

Stripping the thorn of his hoary crown!

Oak or Ash-what matter to thee?

'T was the same to my wild Cherry-tree.

Never at rest, like one that's young Abroad to the winds its arms it flung, Shaking its bright and crowned head, Whilst I stole up for its berries redBeautiful berries! beautiful tree I Hurrah! for the wild wild Cherry-tree!

Back I fly to the days gone by, And I see thy branches against the sky, 


\section{6}

\section{POETRY OF}

I see on the grass thy blossoms shed, I see (nay I taste) thy berries red, And I shout-like the tempest loud and free, Hurrah! for the wild wild Cherry-tree.

Barky Cornwall.

\section{HAREBELL.}

Have ye ever heard in the twilight dim,

A low soft strain,

That ye fancied a distant vesper hymn,

Borne o'er the plain

By the Zephyrs that rise on perfumed wing When the sun's last glance is glimmering?

Have ye heard that music with cadence sweet, And merry peal,

Ring out like the echoes of fairy feet O'er flowers that steal?

And did ye dream that each trembling tone Was the distant vesper-chime alone? 
FLOWERS.

The source of that whispering strain I'll tell,

For I've listened oft

To the music faint of the Blue Harebell,

In the gloaming soft,

'Tis the gay fairy folk that peal who ring

At even-time for their banqueting.

And gaily the trembling bells peal out

With gentle tongue,

While elves and fairies career about

'Mid dance and song.

$\mathrm{O}$ ! roses and lilies are fair to see

But the wild Blue-Bell is the flower for me.

\section{THE CHIME OF THE HAREBELL.}

Over the moorland, over the lea,

Dancing airily, there are we;

Sometimes, mounted on stems aloft,

We wave o'er Broom and Heather,

To meet the kiss of the zephyr soft:

Sometimes close together.

3* 
Tired of dancing, tired of peeping,

Under the whin you'll find us sleeping :

Nodding about and dreaming too;

Dreaming of fairy cups of dew-

Dreaming of music, soft and low

As the melodies that flow

In tiniest ripples along the pool,

In summer twilights dim,

When the night-wind's breath is cool,

And downy owlets skim

Lightly along from shore to shore,

Flitting about, as they bore

Upon their trembling wings

(That ne'er are seen by day)

Dreams and visions, fantastic things,

That people the Lily's slumberings

With a shadowy array

Of forms that flowers know and see

When they are dreaming, e'en as we

Merry Harebells do

On the heathery lea. 
Maiden-do not you

Often wish you were $\mathrm{A}$ flower,

Spending one or two

Merry days in greenwood bower,

As the Harebells do ;

Dancing, and waving, and ringing in glee

Over the moorland and over the lea?

Daintily bend we our honeyed bells While the gossipping bee her story tells, And drowsily hums and murmurs on Of the wealth to her waxen store-house gone, And though she gathers our sweets the while We welcome her in with a nod and a smile.

Darting about,

Now in, now out,

Aloft, adown, in angles, rings,

And every form of swiftest flight,

Like arrows, guided by glittering wings,

The dragon-flies play in the sunshine bright, 
60.

That tinges their forms of chameleon hue With emerald, ruby, amber, blue. You'd fancy a rainbow's painted dome A fitting home For creatures so airy, so light, so gay, As the dragon-flies all in the breeze to play, And poised on the tips Of their tiny feet, They steal from our lips A kiss so fleet That ere our delicate heads are tost, In feigned anger, the thief is lost, Gone-flitting along o'er moor and lea Where the thistle-down sails so airily.

How soft in the gloaming

Our melody floats, When night-winds are roaming And wafting our notes Around and about in cadence sweet ! Oft when this breezy strain ye meet,

Ye gaze around, Chasing the sound, 
And, marvelling whence the strain is springing,

Murmur " how softly the wind is singing!"

We chime too gently for ye to tell

The silvery voice of the little Harebell.

No rock is too high-no vale too low-

For our fragile and tremulous forms to grow;

Sometimes we crown

The eastle's dizziest tower, and look

Laughingly down

On the pigmy man in the world below,

Wearily wandering to and fro.

Sometimes we dwell on the cragged crest

Of mountain high;

And the ruddy sun, from the blue sea's breast

Climbing the sky,

Looks from his couch of glory up,

And lights the dews in the Harebell's cup.

We are crowning the mountain

With azure bells, 
.Or decking the fountain In forest dells,

Or wreathing the ruin with clusters gay, And nodding and laughing the live-long day, When chiming our lullaby, tired with play.

Are we not beautiful? $\mathrm{O}$ ! are not we The darlings of mountain, and moorland, and lea?

Plunge in the forest-are we not fair?

Go to the high road-we'll meet ye there, $O$ ! where is the flower that content may tell Like the laughing, and nodding, and dancing Harebell.

\section{TO A NARCISSUS IN JANUARY.}

How beautiful art thou, my Winter-Flower ! Lifting with graceful pride thy stately head, Heavy with its rich crown of pearl and gold :Thou sheddest on the air such soft perfume That I could deem 'was incense, gently flung 
Before thy beauty's shrine by some fair sprite Enamored of thy maiden loveliness.

The hyacinth and violet entwined Have scarce so sweet an odor.

Thanks, my Flower,

My gentle, kind companion-for to me Thy silence is most eloquent:-I love Thy quiet steadfast gaze, as, o'er my desk, The long day through thou hast seemed watching me;

And ever and anon, in glancing up, I still have met thy calm unchanging look, Reminding me, in silence, of a friend Whose gift thou wert to me. Yet thou wert then

A mere unsightly root. $\mathbf{O}$ ! how I watched With almost childish eagerness, thy growth, And tended thee with more than common care. How rich is my reward! My gentle flower, I fain would never lose thee; but thou'It dieDroop-wither-pass away like all fair things ; Like all I ever loved. 
64

POETRY OF

But yet, not lost,

Not lost, my beautiful; thou wilt but hide Thy quiet loveliness while Summer's Sun Calls forth the courtiers of his glittering train To revel in their gay and festal 'tire:

When Autumn dims them, and when winter chills,

Thou wilt lay by thy cloak or russet brown, And spring up bright and beautiful once more. So when thy fragrance breathes its faint perfume

And pallid droop thy petals round the stem, I will but think thy life one day has spent, And bid thee sweet sleep till me meet again.

\section{THE WALL FLOWER.}

The Wall flower-the Wall flower,

How beautiful it blooms!

It gleams above the ruined tower,

Like sunlight over tombs; 
It sheds $\mathrm{a}$ halo of repose

Around the wreck of time:

To beauty give the flaunting Rose,-

The Wall flower is sublime.

Flower of the solitary place ! Grey Ruin's golden crown!

That loudest melancholy grace To haunts of old renown :

Thou mantlest o'er the battlement, By strife or storm decayed; And fillest up each envious rent

Time's canker-tooth hath made.

Thy roots outspread the ramparts o'er Where, in war's stormy day, The Douglasses stood forth of yore In battle's grim array;

The clangor of the field is fled, The beacon on the hill

No more through midnight blazes redBut though art blooming still. 
66 POETRY OF

Whither hath fled the choral band That filled the abbey's nave? Yon dark sepulchral yew trees stand O'er many a level grave:

In the belfry's crevices the dove Her young brood nurseth well, Whilst thou, lone flower, dost shed above A sweet decaying smell.

In the season of the Tulip cup, When blossoms clothe the trees, How sweet to throw the lattice up, And scent thee on the breeze : The butterfly is then abroad, The bee is on the wing, And on the hawthorn by the road The linnets sit and sing.

Sweet Wall flower-sweet Wall flower!

Thou conjurest up to me Full many soft and sunny hour Of boyhood's thoughtless glee, 
When joy from out the daisies grew, In woodland pastures green, And summer skies were far more blue Than since they e'er hath been.

Now Autumn's pensive voice is heard A mid the yellow bowers, The robin is the regal bird, And thou the Queen of flowers! He sings on the Laburnum trees, Amid the twilight dim, And Araby ne'er gave the breeze Such scents as thou to him.

Rich is the Pink, the Lily gay, The Rose is summer's guest : Bland are the charms when these decay, Of flowers first, last, and best ! These may be gaudier on the bower, And statelier on the tree; But Wall flower, loved Wall flower, Thou art the flower for me. Delta. 


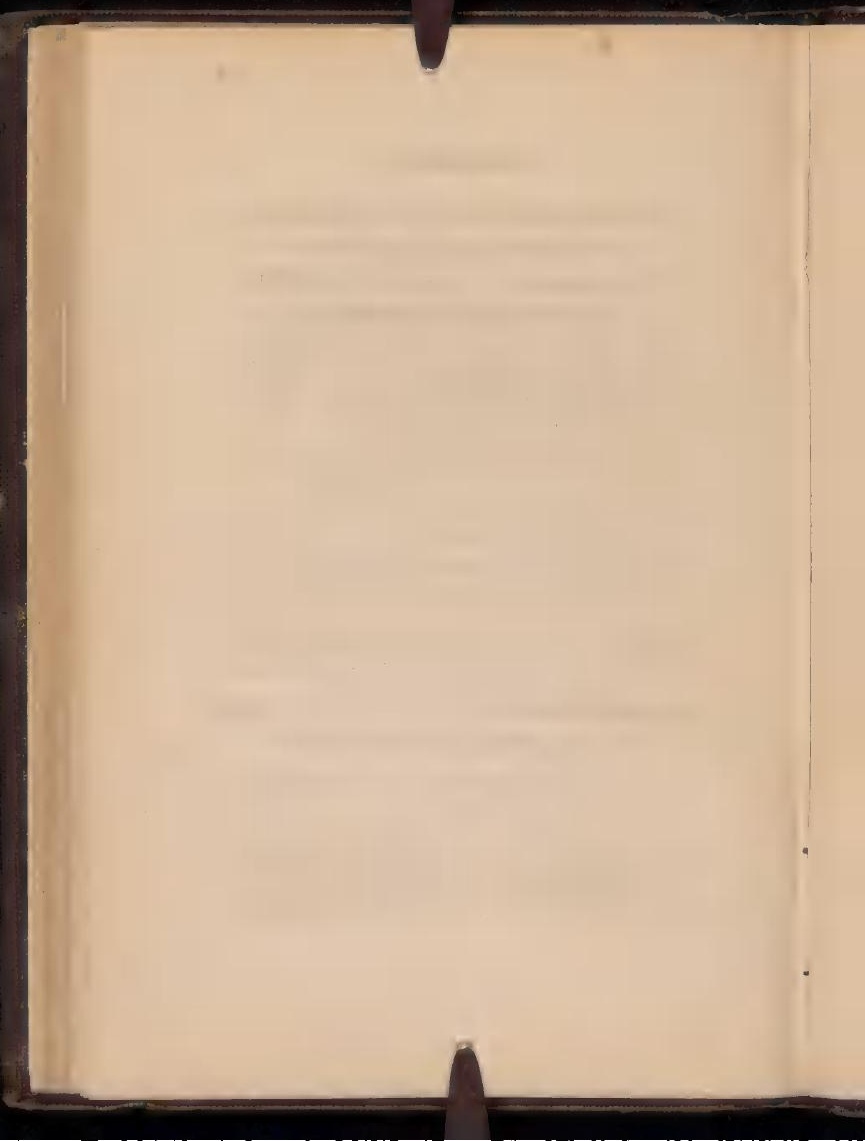




\section{A L U A B E BOOKS}

PUBLISHED BY

\section{SAXTON\& KELT,}

\section{Washington street,}

\section{BOSTON.}

February, 1845.

The Royal Sisters. An historical romance of the middle ages. By Agnes Strickland, 1 vol. $18 \mathrm{mo}$. paper cover,

Same, bound in cloth, .

25 cts.

The Fashionable Wife and Unfashable Husband. By Mrs. Opie, 1 vol. $18 \mathrm{mo}$. paper cover, . . 25 Same, bound in eloth, . . . $37 \frac{1}{2}$ White Lies. By Mrs. Opie, 1 vol. 18 mo. paper covers, . . . 25 Same, in cloth, . . . . $37 \frac{1}{2}$ 
ADVERTISEMENT.

Hand Book of the Sentument and Poetry of Flowers, 1 vol. 32 mo. cloth, gilt edge, . . . . 31 cts.

Actumn Flowers, and other poems, by Mrs. Southey, late Caroline Bowles, 1 vol. 32mo. cloth, gilt edge, . 31

The Loves of the Angers. A Poem by Thomas Moore, 1 vol. $32 \mathrm{mo}$. cloth, gilt edges, .

The Engineer's Text Book, and general Mechanics pocket guide, . 75

Niels Klime's journey under the ground, 1 vol. $12 \mathrm{mo} ., 6$ plates, cloth, . 1,00 The Tongue of Trme: or the language of a Church Clock, 1 vol. $18 \mathrm{mo}$. . . . $37 \frac{1}{2}$ 


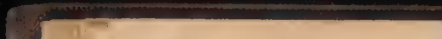




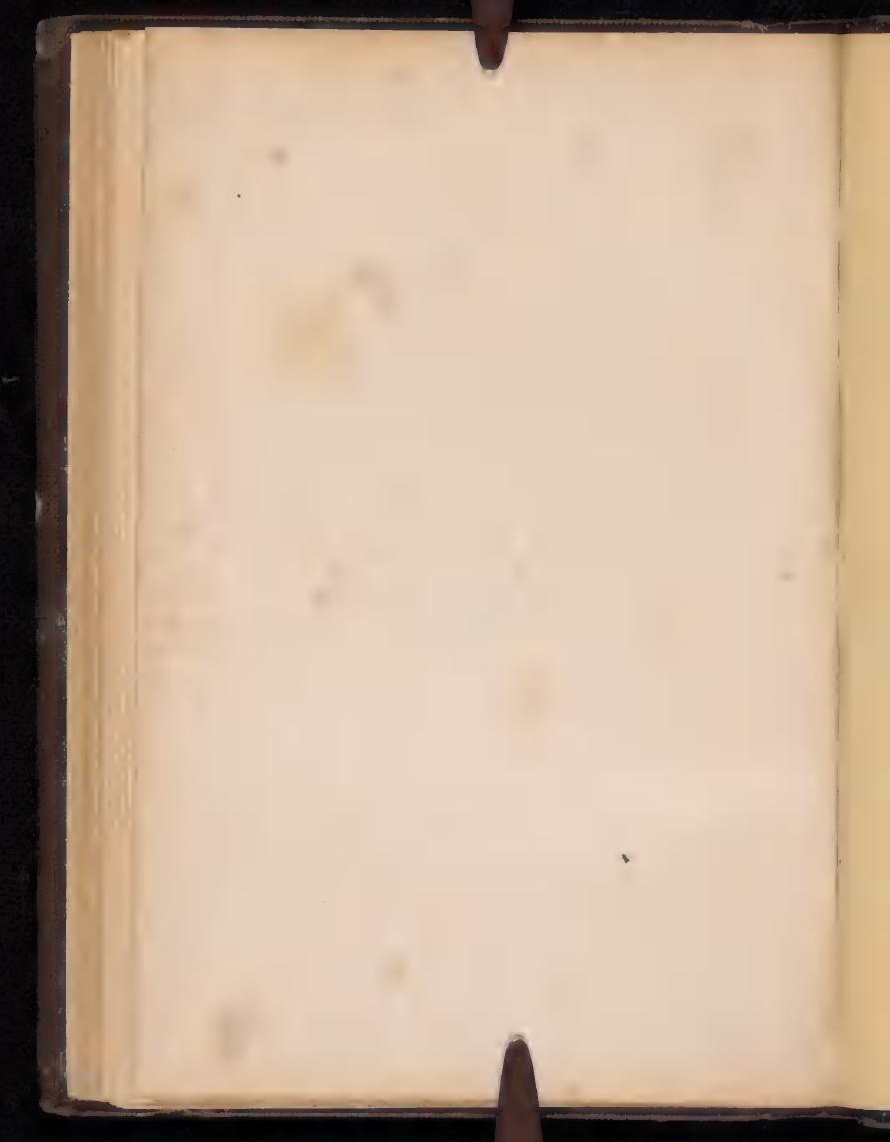





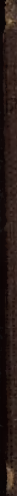

pusinumbe,

mpors my fo

inthithe sing ep 



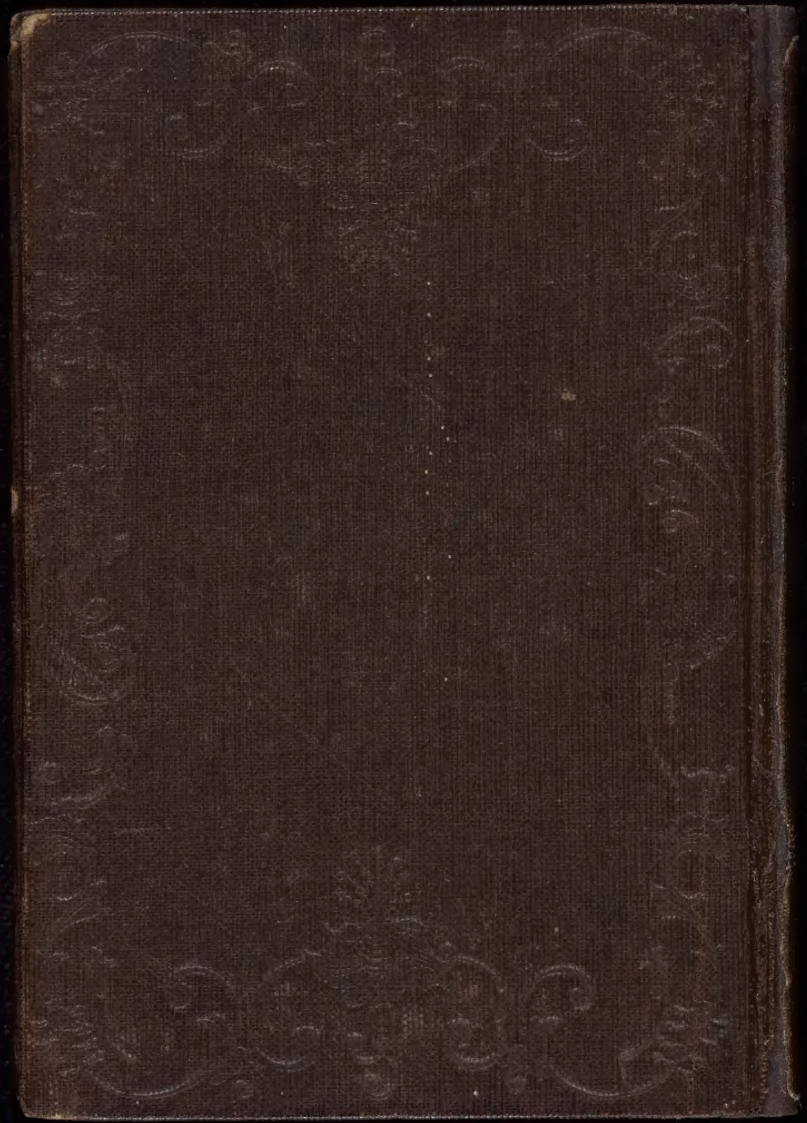

